\title{
POLA ASUH ANAK PEREMPUAN GAYO DALAM PERSPEKTIF GENDER
}

\section{Mahyudin HM dan Nurbaiti}

Sekolah Tinggi Agama Islam ALHIKMAH Jakarta nurbaiti.uin@gmail.com

\section{Absract}

Family is the first social environment where children can interact. It is in this primary institution that a child experiences parenting. Prolonged parenting will form a habit in children. Teaching good habits is very important to do since the beginning of a child's life and education through habituation can be done by giving parenting to children or students.

Parenting between families with one another are different. Many factors can influence parenting by the family. One of the factors that determine the shape of parenting is culture, so that among tribes and others have different forms of parenting.

In providing parenting, the Gayo tribe is strongly influenced by the traditions and culture which they have. They follow to the patrilineal kinship system, which is a fatherly manner, and in principle, this system is a kinship system that draws the lineage of the father or male ancestors.

Boys have a very important role in the kinship system of the Gayo tribe, boys are given an important place, because boys are successors and nobility.

This such parenting is known as gender bias, because boys and girls get different status and roles based on sex (sex) and not based on their abilities.

Keywords: Parenting, Parents, Child, Gender Bias, Gayo Tribe 


\section{Abstrak}

Keluarga merupakan lingkungan sosial pertama tempat anak dapat berinteraksi. Pada institusi primer inilah seorang anak mengalami pengasuhan. Pola asuh yang berkepanjangan akan membentuk sebuah pembiasaan pada anak. Penanaman pembiasaan yang baik, sangat penting dilakukan sejak awal kehidupan anak dan pendidikan melalui pembiasaan dapat dilakukan dengan cara memberikan pola asuh pada anak/siswa.

Pola asuh anak antara keluarga satu dengan keluarga lainnya berbeda-beda. Banyak faktor yang dapat mempengaruhi pola asuh yang dilakukan keluarga. Salah satu faktor yang turut menentukan bentuk pola asuh orang tua adalah budaya, sehingga antara suku satu dengan lainnya mempunyai bentuk pola asuh berbeda.

Dalam memberikan pola asuh, suku gayo sangat dipengaruhi oleh tradisi dan budaya yang mereka miliki. Mereka menganut sistem kekerabatan patrilineal yaitu bersifat kebapaan, dan pada prinsipnya, sistem ini merupakan sistem kekerabatan yang menarik garis keturunan ayah atau garis keturunan nenek moyang laki-laki.

Anaklelaki peranannya sangat penting dalam sistem kekerabatan suku gayo, anaklelaki diberikan tempat yang penting, karena anak lelaki merupakan penerus keturunan dan gelar kebangsawan .

Pola asuh seperti itulah yang kemudian dikenal dengan pola asuh bias gender, karena anak laki-laki dan anak perempuan mendapatkan status dan peranan berbeda berdasarkan jenis kelamin (sex) dan bukan berdasarkan kemampuan yang dimiliki.

Kata Kunci: Pola asuh, orang tua, anak, bias gender, suku gayo. 


\section{A. PENDAHULUAN}

$\mathrm{K}$ eluarga merupakan lingkungan sosial pertama tempat anak dapat berinteraksi, keluarga juga memiliki peran yang sangat penting dan berpengaruh dalam pembentukan dan perkembangan kepribadian. Enrique, et.al menyatakan, keluarga merupakan kesatuan masyarakat terkecil, yang tinggal bersama disebabkan karena kelahiran, perkawinan, atau adopsi atau dengan tinggal bersama karena adanya ikatan emosional yang dekat. ${ }^{1}$

Sedangkan menurut Aziz, pada umumnya sebuah keluarga tersusun dari orang-orang yang saling berhubungan darah. Mereka saling berbagi atap (rumah), meja makan, makanan, uang, bahkan emosi. ${ }^{2}$ Dengan demikian keluarga yang terdiri dari ayah, ibu dan anak-anaknya merupakan institusi pendidikan primer sebelum seorang anak mendapatkan pendidikan di lembaga lain. Pendidikan yang diperoleh anak dari keluarga dalam bentuk pola asuh.

Pola asuh oleh Enrique, et.al dinyatakan sebagai kegiatan kompleks yang mencakup banyak perilaku spesifik yang dapat mempengaruhi outcome anak. ${ }^{3}$ Pola asuh atau gaya pengasuhan akan mempengaruhi banyak hal terutama pada perilaku dan prestasi akademik anak, ini berarti pola asuh orang tua memainkan peranan penting dalam menentukan prestasi akademik dan pembentukan karakter anak. ${ }^{4}$ Seperti dinyatakan oleh Hidayati, pola asuh orang tua akan menjadi penentu dalam banyak hal, termasuk kepribadian dan pestasi belajar anak. ${ }^{5}$

Joseph juga menyatakan, pola asuh merupakan faktor penting dalam perkembangan anak, sebab perkembangan sosio

1 Jade A. Enrique, Heather R. Howk, and William G. Huitt ." An Overview of Family Development." Educational Psychology Interactive. Valdosta, GA: Valdosta State University. Retrieved [date], from http://www.edpsycinteractive.org/papers/family.pdf, h. 1. h. 9 .

2 Asamaeny Aziz. Kesetaraan Gender dalam Perspektif Sosial Budaya (Makasar: Yapma, 2006),

3 Jade A. Enrique, Heather R. Howk, and William G. Huitt ." An Overview of Family Development." Educational Psychology Interactive. Valdosta, GA: Valdosta State University. Retrieved [date], from http://www.edpsycinteractive.org/papers/family.pdf, h. 8.

4 Turner, dkk. "The Influence of Parenting Styles, Achievement Motivation, and Self-Efficacy on Academic Performance in College Students." Journal of College Student Development 50, 3 (May/ June 2009), h. 337- 344.

5 Awik Hidayati. "Pengaruh Tingkat Pendidikan dan pola asuh orang tua terhadap Prestasi Belajar.” Jurnal Pendidikan 13,3 ( November, 2004), h. 268. 
emosional anak dipengaruhi oleh jenis gaya pengasuhan yang digunakan dalam keluarga. ${ }^{6}$ Pola asuh yang berkepanjangan akan membentuk sebuah pembiasaan pada anak. Pola asuh yang baik akan membentuk hasil yang baik, baik dalam hal kedisiplinan siswa maupun kebiasaan-kebiasaan lainnya. Swaroopa menyataan, pola asuh merupakan upaya dari orang tua menyiapkan anak menjadi penerima dan memainkan peranan kunci dalam pengembangan dan kesuksesan karir anak. ${ }^{7} \mathrm{Hal}$ ini menunjukkan bahwa pola asuh menjadi penentu terbentuknya pembiasaan dalam diri anak.

Pembiasaan merupakan upaya praktis dalam pendidikan dan pembinaan anak. Penanaman pembiasaan yang baik, sangat penting dilakukan sejak awal kehidupan anak. Agama Islam sangat mementingkan pendidikan pembiasaan, dengan pembiasaan itulah diharapkan peserta didik mengamalkan ajaran agamanya secara berkelanjutan. Dengan demikian, kesuksesan pendidikan dapat dilakukan melalui pembiasaan dan salah satu cara membentuk pembiasaan melalui pola asuh.

Pendidikan melalui pembiasaan sesuai dengan teori tabula rasa yang dinyatakan oleh John Lock. Menurut Bashayi dalam teori pendidikan tabula rasa yang didasarkan pada psikologi John Lock menyatakan, saat anak dilahirkan, anak tidak tahu apa-apa, anak hanya melakukan segala sesuatu yang bersifat insting saja. Oleh karena itu Locke menyarankan latihan untuk pendidikan anak agar bisa membuat apa yang dia pelajari sebagai kebiasaan, yang mudah dan alami, sehingga anak bisa memperbaiki dirinya melalui pembiasaan yang telah dilakukannya. ${ }^{8}$

Pendidikan melalui pembiasaan juga sesuai dengan teori yang dikemukakan oleh Thorndike, yang menyatakan bahwa pendidikan dapat terjadi melalui pembiasaan dengan memberikan stimulus. ${ }^{9}$

6 Mary Venus Joseph. “ Imfact of Parenting Styles onChild Development." Global Academic Society Journal 1,5 (2008), h. 24.

7 B. Swaroopa. "Impact of Parenting Styles on Career Choices of Adolescents." Journal of Education \& Social Policy 1,1 (June, 2014), h. 19.

8 Ariks Samuel Bahasyi. "Tabula Rasa Theory: A Basis for Creativity and Inventions in Education." Journal of Resourcefulness and Distinction 11,1 ( December, 2015), h. 1.

9 John A. Nevin." Analyzing Thorndike's Las of Effect : The Question of Stimulus- Respons Bonds. Journal of TheExperimental Analysis of Behavior 72,3 (1999), h. 447. 
Demikian juga dengan teori Ivan Pavlov yang juga menyatakan tentang pentingnya stimulus dalam pembiasaan. ${ }^{10}$

Pendidikan yang diterima anak melalui pembiasaan diperoleh melalui pola asuh dalam keluarga. Namun pola asuh antara keluarga satu dengan keluarga lainnya berbeda-beda. Banyak faktor yang dapat mempengaruhi pola asuh yang dilakukan keluarga. Salah satu faktor yang turut menentukan bentuk pola asuh orang tua terhadap anaknya adalah budaya. Pengasuhan seorang anak dilakukan menurut nilai budaya yang diyakini oleh kedua orangtuanya. Proses sosialisasi nilai budaya tersebut dapat dilakukan melalui komunikasi baik secara verbal maupun komunikasi non verbal antara orangtua dan anak.

Chang menyatakan, pola asuh orang tua kepada anaknya dipengaruhi oleh warisan budaya orang tua sendiri, ${ }^{11}$ sehingga pola asuh merupakan warisan budaya yang didapatkan dari para orang tua, yang kemudian diperlakukan kepada anak mereka. Adanya perbedaan suku dan perspektif gender menyebabkan perbedaan pola asuh, karena setiap suku mempunyai budaya sendiri-sendiri.

Dalam hal gender, penelitian ini membantah teori Nature yang dikemukakan oleh Aristoteles yang menyatakan bahwa perbedaan peran disebabkan oleh perbedaan jenis kelamin, ${ }^{12}$ sehingga adanya pemisahan peran bukan disebabkan oleh kemampuan tetapi oleh jenis kelamin.

Lebih lanjut dinyatakan oleh Alen, bahwa Aristoteles dinyatakan sebagai pendiri polaritas seks karena dia adalah filusuf pertama yang berpendapat secara konsisten ada perbedaan filosofis yang signifikan antara pria dan wanita dan pria itu pada hakikatnya

10 Chris Janiszewskiluk and Luk Warlop. "The Influence of The Classical Conditioning Procedures on Subsquent Attention to The Conditioned Brand."Journal of Consumer Research 20,2 (Sep., 1993), h. 173.

11 Mimi Chang. "Cultural Differences in Parenting Styles and their Effects on Teens' SelfEsteem, Perceived Parental Relationship Satisfaction, and Self Satisfaction.” Theses (Carnegie Mellon University, 2007), h. 6.

12 Akar debat pengasuhan Nature di dalam psikologi ditinjau secara singkat, yaitu Nature atau alam (yaitu, pengaruh genetik) dan Nurture (pengaruh sosial-lingkungan) menawarkan dua perspektif yang berbeda tentang kepribadian manusia dan tingkah laku. Lihat Austin D. Miller. "An Overview of the Nature-Nurture Debate and a Proposed New Paradigm. "Intuition Vol 7, (Spring, 2011), h. 34-38. 
lebih tinggi daripada wanita. Aristoteles mengembangkan sebuah teori yang kemudian menjadi dasar untuk netralitas seks, yaitu bahwa diferensiasi seksual tidak signifikan terhadap logika yang berfokus pada ilmu pengetahuan universal, dan bukan pada individu tertentu. ${ }^{13}$

Hal ini menunjukkan bahwa perbedaan peran bukanlah disebabkan oleh jenis kelamin, tetapi lebih pada kemampuan yang dimiliki seseorang.

Penelitian ini mendukung teori Nurture yang menyatakan bahwa perbedaan peran bukan ditentukan oleh jenis kelamin, tetapi oleh lingkungan, pendidikan dan status sosial lainnya. Menurut teori Nurture adanya perbedaan perempuan dan laki-laki adalah hasil konstruksi sosial budaya sehingga menghasilkan peran dan tugas yang berbeda. Nurture merupakan kebalikan dari Nature, seperti dinyatakan oleh Eagly dan Wood, Nature mengacu pada struktur dan proses biologis dan Nurture mengacu pada pengaruh sosiokultural. ${ }^{14}$

Persepsi dan harapan orangtua tentang perkembangan anak berbeda secara nyata menurut budaya. Pola asuh anak dalam sebuah keluarga juga berkaitan erat dengan pola komunikasi dan relasi gender di dalamnya. Pola asuh orang tua tidak hanya mencakup bagaimana orangtua memperlakukan anaknya tetapi juga bagaimana orangtua mendidik, membimbing dan melindungi anak untuk mencapai kedewasaan dengan nilai, norma dan kebudayaan masyarakat. Hal ini juga terjadi pada masyarakat Gayo.

Gayo adalah suku bangsa yang mendiami dataran tinggi Gayo. Suku Gayo secara mayoritas terdapat di kabupaten Aceh Tengah, Bener Meriah dan Gayo Lues. Ketiga kabupaten itu yang sering dikenal dengan dataran tinggi gayo. Masyarakat Gayo saat ini banyak yang sudah menjadi penduduk DKI Jakarta, mereka tersebar baik di wilayah Jakarta selatan, Jakarta barat, Jakarta

13 Sr Prudence Allen, RSM. "Plato, Arostoteles, And The Concept Of Woman Man in Early Jewish Philosophy." Florelegium 9 (1987), h. 92

14 Alice H. Eagly and Wendy Wood. "The Nature-Nurture Debates: 25 Years of Challenges in Understanding the Psychology of Gender.”Association For Psychological Science XX(X), 1-8 (2013), h. 1 . 
timur, Jakarta pusat bahkan juga di depok dan Bekasi. Namun demikian sebagian besar mereka masih memegang teguh budaya dan tradisi yang dimilikinya.

Dalam memberikan pola asuh, suku gayo sangat dipengaruhi oleh tradisi dan budaya yang mereka miliki. Mereka menganut sistem kekerabatan patrilineal yaitu bersifat kebapaan yang pada prinsipnya, sistem ini merupakan sistem kekerabatan yang menarik garis keturunan ayah atau garis keturunan nenek moyangnya yang laki-laki. Anak lelaki peranannya sangat penting dalam sistem kekerabatannya. Penempatan anak lelaki pada tempat yang penting, karena anak lelaki sebagai penerus keturunan dan gelar kebangsawan.

Sikap suku gayo yang menomorduakan perempuan sebenarnya tidak hanya dalam hal pelayanan. Dalam banyak hal termasuk dalam pengambilan keputusan dan penentuan kebijakan dalam keluarga, perempuan dinomorduakan. Hal ini tentu saja berdampak pada model pola asuh yang diberikan orang tua kepada anak-anaknya.

Pada masyarakat Gayo, terdapat perbedaan peran antara anak laki-laki dengan perempuan. Secara umum perempuan di Gayo berada dalam posisi subordinat terhadap laki-laki. Hal ini karena peran dan kedudukan perempuan dalam masyarakat Gayo merupakan konstruksi sosial yang terbangun atas dasar pemahaman masyarakat atas nilai-nilai kultural.

Secara kultural, keadaan masyarakat Gayo sarat dengan muatan patriarkis yang lebih mengutamakan laki-laki daripada perempuan. Dalam hal ini, perempuan dibatasi fungsinya hanya sebagai pembawa keturunan dan dibatasi pada aktivitas-aktivitas domestik dalam rumah tangga. Hurgronje menyatakan, bagi masyarakat gayo, anak perempuan merupakan tambahan tenaga pencari nafkah, bisa membantu mengerjakan tanah, memelihara ternak dan juga bisa mengerjakan pekerjaan orang tua. ${ }^{15}$

Perempuan kehilangan posisi tawarnya karena perempuan dianggap tidak ambil bagian dalam proses ranah publik. Dalam hal

15 Hurgrnje. Masyarakat Gayo dan Kebudayaan Awl Abad ke 20, Terj. HA. Asnah (Jakarta: Balai Pustaka, 1996), h. 21. 
sosialisasi, sejak kecil anak perempuan dibatasi kepada identifikasi kegiatan rumahtangga. Perempuan mengerjakan pekerjaan memasak, membersihkan dan mengurus rumah tangga, dan sebagainya. Sebaliknya, anak laki-laki dilarang memasuki domain yang secara stereotype adalah domain perempuan, sehingga pada umumnya anak laki-laki gayo tidak mengerjakan pekerjaan rumah tangga, seperti mencuci, memasak dan pekerjaan domestik lainnya.

Anak perempuan gayo juga mengalami subordinat, dimana laki-laki memiliki posisi dominan dalam hal mendidik anak dan pengambilan keputusan, hal ini disebabkan karena adat dan budaya yang sudah tertanam cukup lama. Wanita dididik untuk cenderung mengikuti keputusan suaminya, sehingga hak bicara wanita dalam keluarga relatif kecil. Keadaan ini menyebabkan adanya bias gender dalam pola asuh terhadap anak perempuan dan secara psikologis keadaan ini akan menyebabkan timbulnya dampak negatif terhadap kepribadian dan kesuksesan anak perempuan, terutama dalam hal karir.

Cara orangtua memberikan batasan perilaku secara adil kepada anak perempuan dan anak laki-lakinya akan memungkinkan perkembangan kontrol diri yang baik pada mereka. Anak laki-laki seharusnya juga diberi aturan yang sama dengan anak perempuan, sehingga anak laki-laki akan mengembangkan sifat agresifnya dan mampu mengontrol dirinya dengan baik. Anak laki-laki harus menjaga kehormatannya sama dengan anak perempuan, sehingga mampu mengendalikan perilakunya.

Adanya pelabelan (stereotype) antara ranah laki-laki dan ranah perempuan mengakibatkan terbentuknya kebiasaan dan budaya yang menyebabkan tumbuhnya pola asuh yang berbeda antara anak perempuan dengan anak laki-laki, yaitu anak perempuan dididik pada ranah domestik sedangkan laki-laki pada ranah produktif, demikian juga perempuan dididik dan diberikan pemahaman bahwa mereka dalam banyak hal berada pada kondisi subordinat atau dinomorduakan. Pola asuh demikian disebut dengan pola asuh bias gender. 
Dalam Pola asuh bias gender, anak perempuan kurang mendapatkan kesempatan dalam mengungkapkan diri, bahkan anak perempuan yang asertif ${ }^{16}$ akan dikatakan suka ngeyel. Hal tersebut tentu saja mempengaruhi perkembangan asertivitas yang dapat berpengaruh kepada penyesuaian sosial anak. Seharusnya anak diberi tugas yang sesuai dengan potensi anak, tidak mendasarkan kepada jenis kelamin. Anak laki-laki sebaiknya juga diberi tanggung jawab dalam mengerjakan tugas rumah tangga, sehingga tidak berkembang menjadi anak yang sulit diatur dan tidak empatik.

Dari uraian yang telah dikemukakan, bahwa dalam keluarga Gayo, terdapat diskriminasi sikap orang tua dalam memberikan pola asuh dan hal ini perlu adanya perubahan tentang hal tersebut. Seperti dinyatakan oleh Hooks, diskriminasi atas dasar perbedaan jenis kelamin senantiasa tersosialisasikan melalui orang tua dan lingkungan, maka atas dasar itu feminis harus segera melakukan tantangan dan perubahan. ${ }^{17}$

Anak laki-laki sebaiknya mengembangkan empati dengan belajar memahami orang lain, karena pola asuh bias gender sering menempatkan anak perempuan pada posisi mengalah dan harus lebih memahami orang lain. Kontrol diri, asertivitas, serta empati tersebut akhirnya akan membentuk keterampilan sosial yang memadai, bahkan wanita yang ambisius dan tidak feminim bukan sebagai suatu hal yang dianggap menyalahi kodrat.

Anak perempuan juga harus diberikan pola asuh yang menyebabkan perempuan mempunyai keberanian untuk berkompetisi, tidak mengalami fear of success ketika dewasa. Adanya subordinasi dan stereotype terhadap gender menyebabkan perempuan kurang mendapatkan kesempatan untuk mengungkapkan diri, kurang terampil dalam situasi kompetitif

16 Asertif adalah kemampuan seseorang untuk mengkomunikasikan pikiran, perasaan, dan keinginan secara jujur kepada orang lain tanpa merugikan orang lain. Apabila kita mampu mengungkapkan perasaan negatif (marah, jengkel) secara jujur sesuai dengan apa yang kita rasakan tanpa menyalahkan orang lain, maka hal tersebut dapat dikatakan sudah bertindak secara asertif.

17 Hooks berasumsi bahwa diskriminasi atas dasar perbedaan jenis kelamin senantiasa tersosialisasikan melalui orang tua dan lingkungan, maka atas dasar itu feminis harus segera melakukan tantangan dan perubahan. Lihat Bell Hooks. Feminism is for Everybody: Passionate Politics (Cambrigde: South End Press, 2000), h. 7 dan 19. 
yang menuntut pengambilan keputusan secara cepat dan tepat, sedangkan laki-laki lebih terbiasa mengungkapkan diri, maka lakilaki menjadi lebih terampil.

Anak perempuan juga harus tampil dengan kecerdasan, jiwa yang pemberani dan ambisius dan penuh dengan percaya diri, karena hal tersebut bukan hanya harus dimiliki oleh anak laki-laki tetapi juga anak perempuan.

Dengan demikian dapat disimpulkan bahwa pola asuh dapat menjadi penentu kepribadian dan kesuksesan anak, sehingga pola asuh merupakan unsur penting dalam pendidikan. Selama ini pola asuh yang diberikan orang tua kepada anaknya berbeda, tergantung pada budaya setempat, sehingga pola asuh banyak dipengaruhi oleh warisan budaya. Pola asuh yang diberikan orang tua antara anak perempuan dengan anak laki-laki pada masyarakat gayo berbeda berdasarkan gender, sehingga terdapat bias gender dalam pola asuh anak perempuan pada masyarakat Gayo.

\section{B. PEMBAHASAN}

\section{Pola Asuh Orang Tua pada Keluarga Gayo}

Keluarga terutama ibu merupakan lembaga pendidikan pertama bagi anak. Dalam keluarga anak memperoleh bimbingan, arahan dan pembelajaran dansetiap orang tua menginginkan yang terbaik untuk anaknya. Untuk hal tersebut keluarga memberikan pola asuh agar anak tumbuh dan berkembang sesuai dengan yang diharapkan. Pola asuh orang tua terhadap anak dipengaruhi oleh banyak faktor. Salah satunya adalah faktor budaya.

Kebudayaan mempunyai hubungan yang sangat erat dengan masyarakat. Budaya antara lain mengandung nilai-nilai dan norma sosial, budaya jugaditurunkan dari satu generasi ke generasi berikutnya. Biroku dan kawan-kawan menyatakan, budaya adalah konsep yang diartikan sebagai keseluruhan kompleks perilaku tradisional yang telah dikembangkan oleh 
umat manusia dan dipelajari secara berturut-turut oleh setiap generasi, budaya juga memberikan pengaruh terhadap perilaku masyarakat. ${ }^{18}$ Dengan demikian, pola asuh merupakan salah satu prilaku masyarakat yang dipengaruhi oleh budaya.

Hal ini juga terjadi dalam pola asuh orang tua pada keluarga Gayo. Dalam melakukan pola asuh, orang tua Gayo banyak dipengaruhi baik oleh pola asuh yang dilakukan orang tua sebelumnya, maupun pengaruh budaya yang terdapat pada masyarakat tersebut.

\section{Sikap Keluarga Terhadap Ayah dan ibu Pada Keluarga Gayo}

Gayo merupakan salah satu suku yang terdapat di wilayah Aceh dan menganut sistem kekerabatan patrilineal, yaitu adat masyarakat yang mengatur alur keturunan berasal dari pihak ayah. Patrilineal berasal dari dua kata bahasa Latin, yaitu pater yang berarti ayah, dan linea yang berarti garis. Jadi, patrilineal berarti mengikuti garis keturunan yang ditarik dari pihak ayah. Kata ini seringkali disamakan dengan patriarkat atau patriarki, meskipun pada dasarnya memiliki arti yang sedikit berbeda.

Sementara itu, patriarkat berasal dari dua kata bahasa Yunani, yaitu pater yang berarti "ayah", dan archein yang berarti memerintah. Jadi, patriarkat atau patriarki berarti kekuasaan berada di tangan ayah atau pihak laki-laki. Dengan demikian, terdapat sedikit perbedaan antara patrilineal dan patriarki, dimana patrilineal mengikuti garis keturunan ayah dan patriarki kekuasaan ada di tangan ayah. Namun pada umumnya pada sistem patrilineal juga berlaku sistem patriarki.

Sultana menyatakan patriarki merupakan sistem kekeluargaan yang menyatakan keunggulan alami laki-laki daripada perempuan dan menjunjung tinggi ketergantungan perempuan, dan sikap tunduk perempuan dalam semua bidang kehidupan. Akibatnya, semua kekuatan dan wewenang

18 Aliaksandr Birukou dan kawan-kawan. "A Formal definition Of Culture." Technical Report DISI-09-021Accepted for the Workshop on Modeling Intercultural Collaboration and Negotiation (MICON) at International Joint Conference on Artificial Intelligence (IJCAI'09) (June, 2009), h. 4. 
di dalam keluarga, masyarakat dan negara tetap sepenuhnya berada di tangan laki-laki. ${ }^{19}$

Dengan demikian, dalam hal pola asuh dalam penelitian ini yang dilihat adalah sistem patrilineal dan patriarki dan yang dimaksud dengan keluarga Gayo adalah keluarga batih, yaitu keluarga yang terdiri dari ayah, ibu dan anak-anaknya, ${ }^{20}$ dimana kedua orang tua berasal dari Gayo atau ibu mereka saja yang berasal dari Gayo. Hal ini disebabkan pada keluarga Gayo pola asuh orang tua lebih kepada pola asuh ibu kepada anak mereka dan bukan suatu hal yang mustahil, jika terjadi hal yang tidak baik pada anak, maka ibunyalah yang disalahkan, karena dalam masyarakat Gayo, ibulah penentu pertama dalam membentuk kepribadian dan kesuksesan anak.

Sama seperti pada keluarga pada umumnya, dalam keluarga Gayo, kedudukan ayah dan ibu sama, dalam arti sama-sama melakukan kekuasaan demi keselamatan, kebahagiaan dan kesejahteraan seluruh anggota keluarga mereka.Anak-anak pada keluarga Gayo sangat meghormati kedua orang tuanya.

Dari penelitian yang telah dilakukan pada keluarga Gayo yang tinggal di sekitar kota Jakarta, Bogor, Depok, Tangerang Selatan dan Bekasi (Jabodetabek) diperoleh hasil sebagai berikut: Bentuk penghormatan keluarga terhadap ayah dan ibu adalah sama, yaitu mereka menghormati ayah dan ibu sebagai orangtua mereka dan tidak berani membantah kedua orang tua mereka. ${ }^{21}$

Namun dalam hal-hal tertentu, ayah mendapatkan perlakukan lebih istimewa dibandingkan ibu. Hal ini terutama dalam aktivitas sehari-hari. Dari hasil wawancara dengan keluarga Gayo yang ada di Jabodetabek diperoleh hasil, dalam keluarga, ayah mendapat perlakuan istimewa, ayah sangat

19 Abeda Sultana. "Patriarchy and Women's Subordination: A Theoretical Analysis."The Arts Faculty Journal (July 2010-June 2011), h. 6. h. 12 .

20 Asamaeny Azis. Kesetaraan Gender dalam Perspektif Sosial Budaya(Makassar: Yapma, 2006),

21 Hasil observasi peneliti pada keluarga Gayo di Jabodetabek pada bulan September sampai November 2017. 
dihormati. ${ }^{22}$

Hal ini bisa dilihat antara lain: ayah memiliki barangbarang khusus yang tidak bisa dipakai oleh anggota keluarga lainnya, yaitu : Adanya gelas ayah, piring ayah, mangkuk ayah, tempat duduk ayah dan hal-hal pribadi lain yang dimiliki ayah, ${ }^{23}$

Berkaitan dengan hal tersebut dalam hal makan bersama keluarga. Pada masyarakat Gayo yang istri/ibu mereka bekerja sebagai wanita karir, makan bersama seluruh keluarga pada pagi dan siang hari, hanya pada waktu tertentu saja, seperti pada saat weekend atau hari libur lainnya. Pada saat makan bersama tersebut, ayah duduk pada posisi hulu (dalam bahasa Gayo: uken) dan anggota keluarga yang lain pada posisi hilir (dalam bahasa Gayo: Toa). Posisi ayah tidak bisa ditempati oleh anggota keluarga yang lain. ${ }^{24}$

Dalam hal ini, responden kami yang berada di wilayah Jabodetabek juga menyatakan bahwa ayah makan dengan alat-alat makan pribadi yang dimilikinya, posisi duduk pada bagian hulu dan lauk yang dihidangkan juga tersendiri, Hal ini menunjukkan adanya perlakuan istimewa pada ayah dibandingkan anggota keluarga lainnya, termasuk ibu. ${ }^{25}$ Selanjutnya RW menambahkan Jika dalam anggota keluarga ada anak laki-laki yang sudah menikah, maka anak tersebut diberikan posisi khusus setelah ayah. Sedangkan anak laki-laki yang belum menikah, anak perempuan dan ibu berada pada posisi yang sama. ${ }^{26}$

Perbedaan sikap keluarga terhadap ayah dan ibu disebabkan karena perbedaan jenis kelamin, yang berdampak pada ketidak

22 Hasil observasi peneliti pada keluarga Gayo di Jabodetabek pada bulan September sampai November 2017.

23 Hasil observasi peneliti pada keluarga Gayo di Jabodetabek pada bulan September sampai November 2017.

24 Hasil observasi peneliti pada keluarga Gayo di Jabodetabek pada bulan September sampai November 2017 dan hasil wawancara dengan responden kami yang ada di wilayah Jabodetabek pada bulan Oktober 2017.

25 Hasil observasi peneliti pada keluarga Gayo di Jabodetabek pada bulan September sampai November 2017 dan hasil wawancara dengan responden kami yang ada di wilayah Jabodetabek pada bulan Oktober 2017.

26 Hasil wawancara dengan RW di wilayah Tangerang Selatan pada tanggal 30 September 2017. 
adilan gender ${ }^{27}$. Ibu berada pada posisi yang tidak setara dengan ayah karena ibu adalah perempuan. Hal ini terjadi karena dalam masyarakat dimana laki-laki mendominasi perempuan. Seperti dinyatakan oleh Shastri bahwa perempuan didiskriminasi dalam masyarakat yang mendominasi laki-laki dan diskriminasi dipengaruhi oleh norma budaya dan tradisi, agama, daerah, dll. Secara biologis dan sosiologis keduanya diberi perlakuan yang berbeda. ${ }^{28}$

Hal ini juga menunjukkan pada keluarga Gayo, secara kultural menomorduakan perempuan, dalam istilah gender subordinat. Posisi ibu tidak setara dengan ayah. Ayah dilayani, ibu dan anak-anak perempuan melayani. Adanya barang-barang khusus untuk ayah, seperti piring ayah, gelas ayah, mangkukayah dan barang pribadi milik ayah yang tidak bisa digunakan oleh anggota keluarga yang lain termasuk ibu, juga menunjukkan bahwa ayah dan ibu berada tidak pada posisi yang sama.

Hal ini juga menunjukkan telah terjadi bias gender ${ }^{29}$ dalam keluarga, karena selayaknya ibu berada pada posisi yang sama dengan ayah, baru setelah itu anak-anak mereka. Dengan kata lain, jika ada barang-barang khusus untuk ayah, mengapa tidak ada barang-barang khusus untuk ibu. Demikian juga dalam pengambilan keputusan dan dalam melaksanakan pekerjaan baik pada ranah publik maupun domestik, perempuan mengalami diskriminasi.

Bias gender yang terjadi pada perempuan keluarga Gayo tidak hanya sebatas yang telah disebutkan, yaitu ayah mendapatkan perlakuan lebih istimewa dibandingkan ibu dalam keluarga, tetapi bias gender juga sering terjadi dimana

27 Ketidak adilan gender adalah perilaku yang dibentuk secara kultural yang ada pada laki-laki (maskulin) atau perempuan (feminim) dan lebih memihak kepada salah satu dari keduanya. Lihat Moh. Khuza'i. "Problem Definisi Gender: Kajian atas Konsep Nature dan Nurture." Kalimah 11,1 (Maret, 2013), h. 102.

28 Andrey Shastri. "Gender Inequality and Women Discrimination." IOSR Journal Of Humanities And Social Science (IOSR-JHSS) 19, 11, Ver. VII (Nov. 2014), h. 27.

29 Bias gender didefinisikan sebagai pemisahan berdasarkan jenis kelamin, dengan cara lebih memihak kepada salah satu jenis kelamin. Dengan kata lain bias gender adalah pemisahan peran yang didasarkan perbedaan jenis kelamin. Lihat: Mahadevappa. T .C. "Gender Bias and Social Justice."IOSR Journal Of Humanities And Social Science (JHSS) 4, 2 (Nov. - Dec. 2012), h. 42. 
perempuan lebih banyak bekerja dibandingkan dengan lakilaki, baik pada ranah reproduksi yang memang secara alami tidak bisa dilakukan oleh laki-laki, ranah domestik yaitu mengerjakan pekerjaan rumah tangga maupun ranah publik untuk membantu perekonomian keluarga.

Goswami menyatakan, diskriminasi gender biasanya terjadi pada situasi yang mengacu pada beban kerja perempuan yang berat dan banyak tugas tumpang tindih yang terlibat, yang jika dihitung dalam hitungan jam akan mencapai lebih dari 24 jam. Beban kerja ini terdiri dari pekerjaan reproduksi yang tidak dibayar, pekerjaan produktif yang dibayar, dan semua pekerjaan rumah tangga lainnya yang diperlukan untuk kelangsungan hidup keluarga. ${ }^{30}$ Dengan demikian, adanya perbedaan perlakuan antara laki-laki dan perempuan pada keluarga Gayo menunjukkan telah terjadi bias gender dalam keluarga.

\section{Pembagian Peran Dalam Keluarga}

Pembagian peran dalam keluarga merupakan hal yang penting, Karena dengan adanya pembagian peran, maka akan tercipta keluarga yang saling menghargai dan berbagi. Terdapat dua teori yang berhubungan dengan teori peran lakilaki dan perempuan yang berlawanan, yaitu teori nature dan teori nurture.

Teori nature yang menyatakan bahwa perbedaan peran gender bersumber dari perbedaan biologis laki-laki dan perempuan. Sedangkan teori nurture menyatakan bahwa perbedaan peran gender antara laki-laki dan perempuan bukan merupakan konsekuensi dari perbedaan biologis yang kodrati, namun lebih sebagai hasil konstruksi manusia, sehingga peran tersebut masih bisa dipertukarkan.

Seperti dinyatakan oleh Eagly an Woo, bahwa teori nature lebih menunjukkan pada proses biologi dan nature teori lebih

30 Sribas Goswami. "Persistent Inequalities : Sribas Goswami." American International Journal of Research in Humanities, Arts and Social Sciences, 4, 1 (September-November, 2013), h. 98. 
kepada pengaruh sosiokultural. ${ }^{31}$ Dengan demikian, perbedaan pembagian peran dalam gender dibentuk oleh budaya, hubungan sosial, dan lingkungan alam.

Dari hasil penelitian yang telah dilakukan, diperoleh hasil bahwa pada keluarga Gayo terdapat pembagian peran antara laki-laki dan perempuan berdasarkan jenis kelamin. Pembagian peran tersebut tidak berdasarkan para pertimbangan kemampuan yang dimiliki, tetapi lebih didorong oleh faktor kedudukan laki-laki, dalam hal ini suami. Semua pekerjaan lakilaki oeh masyrakat Gayo dianggap harus terhormat, karena laki-laki adalah pemimpin (Imem $)^{32}$ keluarga. Dengan demikian, pembagian pekerjaan laki-laki dan perempuan bukanlah atas kehendak bebas, melainkan hasil kontruksi masyarakat.

Menurut masyarakat Gayo laki-laki tidak boleh melakukan pekerjaan wanita. Pada keluarga gayo adanya garis pemisah yang cukup signifikan antara ranah pekerjaan laki-laki dengan ranah pekerjaan perempuan. Pekerjaan laki-laki berada pada ranah publik, yang berarti suami yang mencari nafkah, sedangkan perempuan bekerja pada ranah domestik, yaitu mengerjakan semua pekerjaan rumah tangga, seperti mencuci, memasak, memelihara anak dan pekerjaan rumah tangga lainnya. Pelanggaran terhadap hal tersebut dapat mengakibatkan diperolehnya sanksi, baik dari anggota keluarga maupun anggota masyarakat. Sanksi yang diberikan berupa cemoohan dan aib keluarga.

Begitu tegasnya pembagian peran pekerjaan antara lakilaki dan perempuan, sehingga sejak dini anak perempuan diajarkan hal-hal yang berhubungan dengan hal tersebut. Perempuan diajarkan tentang pendidikan agama, tata karma, sopan santun, taat kepada suami yang kelak dimilikinya dan diajarkan semua pekerjaan domestik. ${ }^{33}$

31 Alice H. Eagly1 and Wendy Wood. "The Nature-Nurture Debates: 25 Years of Challenges in Understanding the Psychology of Gender."Perspectives on Psychological Science xx, x (2013), h. 1-18.

32 Imem dalam bahasa Gayo yang berarti pemimpin dalam bahasa Indonesia.

33 Hasil observasi pada keluarga Gayo di wilayah Jabodetabek sejak September sampai dengan November 2017 
Ranah (domain) perempuan pada ranah domestik antara lain: mencuci pakaian, mencuci piring, memasak, menghidangkan makanan dan pekerjaan rumah tangga lainnya, disamping juga pendidikan pada sekolah formal tentunya. ${ }^{34}$ Anak laki-laki tidak diajarkan tentang pekerjaan domestik tersebut. Hal ini didasarkan anggapan bahwa ranah pekerjaan laki-laki adalah ranah publik dan bukan ranah domestik.

Perbedaan peran antara perempuan dan laki-laki merupakan bentuk bias gender, yaitu keberpihakan kepada salah satu gender berdasarkan perbedaan jenis kelamin, dalam pola pengasuhan para orang tua Gayo terhadap anak perempuan mereka.

Peran laki-laki sebagai pekerja publik dalam keluarga Gayo, bisa dilakukan secara bersama dengan ibu, jadi tidak jarang para perempuan Gayo selain bekerja pada ranah domestik juga bekerja pada ranah publik. Pekerjaan para perempuan Gayo yang tinggal di Jabodetabek pada ranah publik adalah sebagai guru atau pendidik, sebagai Pegawan Negeri Sipil (PNS) dan wira usaha.

Tidak jarang ditemui di lapangan, bahwa perempuan Gayo yang bekerja di wilayah publik, seperti para perempuan yang merupakan responden kami, mereka bekerja pada wilayah publik, sebagai PNS, wiraswasta dan pekerja guru honorer. Hanya dua responden kami yang bekerja hanya pada ranah domestik, yaitu sebagai ibu rumah tangga, yaitu II dan istri dari bapak HA. ${ }^{35}$

Perbedaan antara peran laki-laki dan perempuan yang didasarkan pada gender, merupakan perdebatan antara teori nature dan nurture. Penelitian ini tidak setuju dengan teori nature yang menyatakan bahwa peran perempuan merupakan hal yang bersifat kodrati, artinya identitas gender adalah suatu hal kodrati, karena perbedaan peran yang didasarkan

34 Hasil observasi pada keluarga Gayo di wilayah Jabodetabek sejak September sampai dengan November 2017

35 Hasil observasi pada keluarga Gayo di wilayah Jabodetabek sejak September sampai dengan November 2017. 
kodrati, hanya berdasarkan hal-hal biologis yang tidak bisa dipertukarkan, seperti peran perempuan dalam hal menstruasi, mengandung, melahirkan, menyusui anak dan hal lain yang bersifat biologis. Dengan demikian, perbedaan peran berdasarkan perbedaan kondisi biologis itulah yang tidak dapat dipertukarkan.

Perbedaan pembagian peran antaralaki-lakidan perempuan pada keluarga Gayo seharusnya berdasarkan konstruk masyarakat dan kemampuan yang dimiliki, bukan berdasarkan kondisi biologis, sehingga peran tersebut dapat dipertukarkan. Jadi sebenarnya tidak masalah dan bukan merupakan aib keluarga (yang besar) jika seorang laki-laki memasuki ranah domestik, demi untuk membantu istri. Pekerjaan tersebut dapat dipertukarkan atau dilakukan secara bersama.

Penelitian ini menentang teori Nature yang dikemukakan oleh Aristoteles, yang menyatakan bahwa perbedaan peran antara laki-laki dan perempuan merupakan hal yang kodrati (alamiah), sehingga peran antara laki-laki dan perempuan tidak bias berubah. Penelitian ini mendukung teori Nurture yang menyatakan bahwa perbedaan wanita dan pria adalah hasil dari konstruksi sosial budaya, sehingga peran dan tugas yang berbeda antara pria dan wanita masih bisa dipertukarkan. ${ }^{36}$

Seperti dinyatakan Khuza'i, Di antara feminis sendiri ada perdebatan dalam memaknai perbedaan antara laki-laki dan perempuan serta kesetaraan. Pertama, penganut konsep nature yang menganggap perbedaan adalah alami, sehingga kesetaraan yang dibutuhkan adalah keadilan sesuai konteks. Kedua, penganut konsep nurture yang menganggap perbedaan adalah buatan manusia, terutama oleh laki-laki, sehingga dalam menyikapi perbedaan kelompok ini menuntut penghapusan batas-batas gender dan memaknai kesetaran adalah persamaan

36 Nature merupakan hal berkaitan dengan masalah genetic, sedangkan nurture merupakan hal yang berkaitan dengan factor eksternal yang mempengaruhi tingkah laku manusia. Lihat :Eman Ahmed Zaky. "Nature, Nurture, and Human Behavior; an Endless Debate" J Child Adolesc Behav, an open access journal 3,6 (2015), h. 1. 
secara kuantitatif. ${ }^{37}$

Perbedaan peran yang terbentuk karena konstruksi sosial bisa saja dipetukarkan, sehingga bukanlah hal yang memalukan jika laki-laki berada pada ranah domestik, demikian juga sebaliknya, perempuan tidak salah jika berada pada ranah publik. Bentuk kesetaraan gender bisa tercipta, jika pemberian peran bukan berdasarkan kepada perbedaan jenis kelamin, tetapi berdasarkan kemampuan yang dimiliki.

Kesetaraan gender juga bukan membahas pada hal-hal yang bersifat kodrati dan alami, sebagai contoh, peran wanita sebagai perempuan untuk hamil, melahirkan dan menyusui itu merupakan peran perempuan yang bersifat kodrati dan tidak bisa dipertukarkan, namun peran dalam hal melakukan pengasuhan anak dan bekerja pada ranah domestik, hal tersebut tidak bersifat kodrati dan alami, sehingga masih bisa dipertukarkan dan dikerjakan baik oleh laki-laki dan perempuan.

Adanya pandangan aib dan memalukan mengerjakan suatu pekerjaan pada ranah tertentu merupakan bentuk konstruksi masyarakat dan hal tersebut sudah terjadi sejak dulu secara turun temurun, adanya pandangan tentang pelabelan (Stereotype) ranah pekerjaan, merupakan warisan budaya, sehingga dapat disimpulkan bahwa pola asuh merupakan warisan budaya.

\section{Peran Perempuan dalam Pengambilan Keputusan Pada Keluarga Gayo}

Fenomena yang terjadi dalam masyarakat di kota besar seperti Jakarta adalah semakin banyaknya wanita yang berperan membantu suami mencari tambahan penghasilan, selain karena didorong oleh kebutuhan ekonomi keluarga, wanita semakin dapat mengekspresikan dirinya di tengahtengah keluarga dan masyarakat, sehingga mempunyai dampak kepada sikap dan cara berpikir yang mulai berbeda dari masa

37 Moh. Khuza'i. "Problem Definisi Gender: Kajian atas Konsep Nature dan Nurture ." Kalimah 11,1 (Maret, 2013), h. 16. 
lampau. Hal ini juga terjadi pada perempuan gayo yang tinggal di kota Jabodetabek.

Saat ini para perempuan Gayo sudah banyak yang bekerja pada ranah publik, mereka bekerja baik sebagai pegawai negeri (PN), pegawai swasta atau bahkan melakukan wisausaha. Dampak yang diberikan terhadap perekonomian keluarga juga cukup nyata. Para perempuan bekerja untuk membantu perekonomian keluarga. ${ }^{38}$

Hal ini juga berdampak pada cara pengambilan keputusan dalam keluarga. Berdasarkan hasil penelitian diperoleh hasil bahwa dalam pengambilan keputusan sebagian responden menyatakan tidak membedakan antara anak laki-laki dan perempuan, meskipun masih tetap saja ayah sebagai pengambil keputusan (decision maker) dan sebagian responden menyatakan keterlibatan perempuan dalam pengambilan keputusan relatif kecil. ${ }^{39}$

Dengan demikian dapat disimpulkan, bahwa pola asuh orang tua Gayo pada anaknya didasarkan kepada konstruk budaya yang telah diturunkan secara turun temurun dalam waktu yang cukup lama.

\section{Pengaruh Budaya terhadap Bentuk Pola Asuh Orang Tua Gayo}

Pola asuh orang tua merupakan perilaku orang tua dalam interaksi yang meliputi orang tua menunjukan kekuasaan dan orang tua memperhatikan keinginan anak. Pola asuh yang diberikan keluarga, erat kaitannya dengan sikap dan tingkah laku yang dilakukan oleh seseorang. Setiap suku yang ada di Indonesia mempunyai adat dan kebiasaan yang berbeda, sehingga memunculkan beragam tata asuh yang berbeda.

Pembatasan-pembatasan pada perempuan dan kebebasan pada laki-laki merupakan bentuk ketidak adilan gender dan hal

38 Hasil observasi pada keluarga Gayo di wilayah Jabodetabek sejak September sampai dengan November 2017.

39 Hasil Wawancara pada keluarga Gayo di wilayah Jabodetabek sejak September sampai dengan November 2017. 
ini sudah terjadi sejak dulu, sehingga bentuk pola asuh yang diterapkan kepada anak-anak mereka sebagai bentuk warisan budaya dari para orang tua mereka.

Perbedaan antara laki-laki perempuan juga terkait dengan budaya. Perbedaan ini biasanya dikaitkan dengan bagaimana konstruksi budaya tentang peran, fungsi dan sumbangan lakilaki atau perempuan di dalam kehidupan sosial, politik, dan budaya. Inilah yang sering menyebabkan adanya perbedaan gender .

Pola asuh merupakan sikap orang tua dalam membesarkan anak. Pola asuh yang diterapkan orang tua merupakan budaya yang diterapkan secara turun temurun, dengan demikian, pola asuh merupakan warisan budaya. Seperti dinyatakan oleh Chang an Bornstein

Chang menyatakan bahwa Jenis gaya pengasuhan yang digunakan oleh orang tua dapat ditentukan oleh warisan budaya orang tua. ${ }^{40}$ Bornstein juga menyatakan bahwa budaya dipahami sebagai seperangkat pola khas dari kepercayaan dan perilaku yang dimiliki oleh sekelompok orang dan yang berfungsi untuk mengatur kehidupan sehari-hari mereka. Keyakinan ini menunjukkan bagaimana orang tua merawat anak mereka. ${ }^{41}$

Kedua pernyataan tersebut menunjukkan bahwa budaya memberikan pengaruh terhadap pola pengasuhan orang tua terhadap anaknya. Dari wawancara kami pada para orang tua Gayo juga menyatakan, bahwa apa yang mereka lakukan saat ini dalam mengasuh anak, disebabkan mereka juga dididik seperti itu oleh orang tua mereka. ${ }^{42}$

Bentuk pola asuh yang diberikan para orang tua Gayo

40 Mimi Chang. "Cultural differences in parenting styles and their effects on teens' self-esteem, perceived parental relationship satisfaction, and self-satisfaction." Dietrich College of Humanities and Social Sciences (2007), h. 6.

41 Marc H. Bornstein. "Cultural Approaches to Parenting." Parenting : Science An Practice 12 (2012), h. 212.

42 Wawancara dengan orang tua Gayo di Jaboetabek pada bulan September sampai Oktober 2017.

$60 \sim$ HIKMAH, Vol. XIV, No. 1, 2018 
merupakan bentuk pola asuh otoriter. Hal ini bisa dilihat dari bagaimana orang tua menanamkan kebiasaan-kebiasaan terhadap anaknya dan anak cenderung mengikuti aturan yang telah diberikan oleh orang tua mereka. Penerapan pola asuh otoriter oleh orangtua dengan mengontrol perilaku anak berdasarkan standar yang sudah ditetapkan oleh orangtua biasanya didorong oleh motivasi ideologi. Seperti dinyatakan oleh Baumrind, Pola asuh ini cenderung mengontrol anak sebagaimana yang Tuhan harapkan terhadap anak. Hal inilah yang menyebabkan orang tua yang menjalankan pola asuh otoriter tidak memberi ruang pada anak untuk menegosiasikan peraturan karena aturan tersebut dianggap pedoman dari Tuhan. $^{43}$

Selama ini gaya pengasuhan dianggap menghambat perkembangan kepribadian anak. Namun hal ini tidak sesuai dengan pernyataan El-Hafiz dan Al-maududi yang menyatakan, dari beberapa fakta penelitian, pola asuh otoriter tidak mengganggu perkembangan anak, bahkan pola asuh otoriter berdampak positif terhaap perkembangan anak.

Beberapa indikator yang menunjukkan bahwa bentuk pola asuh otoriter pada keluarga Gayo, seperti dinyatakan oleh Azhar antara lain dalam hal sopan santun, melakukan pekerjaan sesuai dengan ranahnya (domestik/publik) dan dalam hal pendidikan agama. ${ }^{44}$

\section{Bentuk-bentuk Bias pada Pola Asuh Orang Tua Gayo}

Mutawakil menyatakan, bentuk-bentuk bias gender atau ketimpangan gender yang sering terjai di masyarakat adalah : marginalisasi perempuan, yakni menjauhkan perempuan dari aktivitas publik, subordinasi perempuan, yaitu menempatkan perempuan pada posisi lebih rendah daripada laki-laki. Karena adanya anggapan perempuan irasional, emosional, lemah, dan lain-lain, stereotip negatif terhadap perempuan, kekerasan

43 Baumrind, D. "Effects of Authoritative Parental Control on Child Behavior". Child development, 37, 4 (1996), h. 889.

44 Wawancara dengan AA/AQ di Jakarta pada Oktober 2017.

HIKMAH, XIV, No. 1, $2018 \sim 61$ 
perempuan, dan beban/peran ganda sebagai pekerja domestik dan pekerja luar. ${ }^{45}$

Bias gender pada keluarga Gayo antara lain adalah: stereotype, double burden dan subrodinat. Steroetype atau pelabelan terjadi pada ranah pekerjaan perempuan, dimana perempuan bekerja pada ranah domestik dan laki-laki bekerja pada ranah publik. Double burden atau peran ganda terjadi jika perempuan berada selain pada ranah domestik juga bekerja pada ranah publik dan subordinat merupakan penomorduaan terhadap perempuan.

Berikut akan disajikan bentuk-bentuk bias gender yang terdapat pada keluarga Gayo, yaitu : stereotype (pelabelan), double burden (peran ganda) dan subordinat (penomorduaan).

\section{a. Gender Stereotype (Pelabelan Gender)}

Gender Stereotype atau pelabelan gender menurut Eagly dan Steven, terjadi karena seringnya sekelompok orang mengamati kelompok tertentu tentang apa yang dilakukannya, sehingga timbul anggapan bahwa atribut kemampuan dan kepribadian merupakan aktivitas khas kelompok tersebut. Contoh, jika sekelompok orang mengamati bahwa merawat anak adalah aktivitas wanita, maka karakteristik yang dianggap penting untuk hal tersebut seperti pengasuhan dan kehangatan adalah tipikal wanita. ${ }^{46}$

Hal ini mengindikasikan bahwa pelabelan gender atau Gender stereotype terjadi karena adanya konstrak masyarakat. Hal ini sesuai dengan teori Nurture yang menyatakan bahwa perbedaan antara laki-laki dan perempuan disebabkan karena konstrak sosial budaya dan bukan hal yang bersifat kodrati, sehingga gender stereotype sebenarnya masih bisa dipertukarkan. h. 72 .

45 M. Hajir Mutawakkil. “Keadilan Islam dalam Persoalan Gender."Kalimah 12,2 (Maret 2014),

46 Alice H. Eagly and Valerie J. Steffen. "Gender Stereotypes Stem From the Distribution of Women and Men Into Social Roles.” Journal or Personality and Social Psychology 46, 4 (1984), h. 735. 
Berdasarkan hasil penelitian yang telah dilakukan terhadap responden (keluarga Gayo) diperoleh hasil, adanya perbedaan ranah pekerjaan antara ranah domestik dan rana publik. Domestik merupakan ranah perempuan dan publik merupakan ranah laki-laki. Laki-laki yang memasuki ranah domestik, dianggap menyalahi adat dan budaya, sehingga merupakan aib. Namun tidak demikian sebaliknya. Perempuan boleh saja bekerja pada ranah publik demi untuk membantu kesejahteraan keluarga. ${ }^{47}$

Seperti dinyatakan sebagian responden kami, jika pada hari libur, dimana anak laki-laki dan anak perempuan berada di rumah, maka anak laki-laki hanya bersantai saja, sementara anak perempuan membantu ibu mengerjakan pekerjaan rumah. Ketika waktu makan siang, laki-laki hanya menunggu, sementara ibu dan anak perempuan mempersiapkan dan menghidangkan makanan. ${ }^{48}$

\section{b. Double Burdent(Peran Ganda)}

Pergeseran dalam peran (pembagian kerja) antara lakilaki dan perempuan dalam keluarga dan rumah tangga, terjadi ketika seorang ibu mempunyai peran yang sangat penting di dalam masyarakat dan Negara. Di mana peran perempuan tidak hanya untuk dipimpin tetapi juga untuk memimpin. Yang dimaksud dengan peran ganda pada perempuan adalah ibu yang berperan dalam pekerjaan domestik dan publik sekaligus. Dalam hal ini perempuan berperan sebagai ibu, sebagai istri, sebagai ibu rumah tangga, sebagai pendidik, sebagai pembawa keturunan dan sebagai anggota masyarakat.

Seperti dinyatakan Hidayati, Beban ganda (double burden) artinya beban pekerjaan yang diterima salah satu jenis kelamin lebih banyak dibandingkan jenis kelamin lainnya. Peran reproduksi perempuan seringkali dianggap

47 Hasil wawancara dan observasai pada keluarga Gayo sejaboetabek pada bulan September sampai bulan November 2017.

48 Hasil wawancara dan observasi pada keluarga Gayo di Jabodetabek pada September sampai November 2017. 
peran yang statis dan permanen. ${ }^{49}$

Dari hasil penelitian diperoleh hasil. Dalam keluarga Gayo, Ibu bisa memasuki baik ranah domestik maupun ranah publik. Hal ini seperti dinyatakan oleh NF, bahwa ranah perempuan adalah ranah domestik, yaitu mencuci, memasak, mengurus anak, dan lain-lain dan ranah ayah adalah ranah publik, yaitu mencari nafkah untuk keluarga. Namun menjadi suatu kebanggaan bagi para perempuan (ibu), jika mampu melakukan pekerjaan selain di ranah domestik juga di ranah publik. Masyarakat akan mengganggap perempuan yang berada di kedua ranah tersebut adalah perempuan hebat.Jika dilihat secara keadilan gender, hal tersebut tidak ada keadilan dan kesetaraan gender. Perempuan bekerja padadua ranah sekaligus.

Hal ini sesuai dengan hasil penelitian Gibb dan kawan-kawan, yang menyatakan, laki-laki lebih banyak menghabiskan waktunya pada pekerjaan berbayar disbanding perempuan, karena perempuan lebih banyak menghabiskan waktu pada pekerjaan rumah tangga, namun secara keseluruhan perempuan lebih banyak menghabiskan waktu baik pada pekerjaan berbayar maupun pekerjaan rumah tangga. ${ }^{50}$

\section{c. Subordinat (Penomorduaan).}

Pekerjaan rumah tangga menghabiskan waktu yang cukup lama, sehingga pembagian waktu dan tugas rumah tangga memiliki implikasi penting bagi kehidupan di luar rumah. Namun dalam pembagian tugas tersebut, perempuan sering ditempatkan pada posisi yang tiak menguntungkan, karena masih adanya anggapan pekerjaan yang dikerjakan perempuan memberikan hasil yang kurang memuaskan, misalnya dalam pengambilan keputusan atau

49 Nurul Hidayati. “Beban Ganda Perempuan Bekerja (Antara Domestik dan Publik)” Muwazah 7, 2 (Desember 2015), h. 108.

50 Sheree J. Gibb, David M. Fergusson and Joseph M. Boden. "Gender Differences in Paid and Unpaid Work findings from a New Zealand birth cohort."Policy Quarterly 9, 3 (August 2013), h. 68. 
mengerjakan pekerjaan lain yang sebenarnya perempuan bias melakukannya sama dengan laki-laki.

Hal ini terjadi karena masih adanya anggapan masyarakat, perempuan bersifat emsional dan tidak rasional, sehingga pekerjaan yang dihasilkan tidak optimal. Dalam perspektif gender dikenal dengan istilah subordinasi. ${ }^{51}$ Subordinasi terjadi karena adanya anggapan bahwa perempuan mempunyai kemampuan lebih rendah dari laki-laki, sehingga perempuan ditempatkan pada posisi tidak strategis (second person).

Reeves dan Baden menyatakan, Perempuan sering mendapatkan perlakuan tidak adil dalam hak, kesempatan dan sumber daya berdasarkan jenis kelamin di semua bidang kelembagaan, termasuk di rumah tangga. Di dalam rumah tangga, perempuan dan anak perempuan dapat menghadapi diskriminasi dalam pembagian sumber daya rumah tangga. ${ }^{52}$

Hal ini juga yang terjadi pada perempuan Gayo. Adanya system patrilineal dalam keluarga Gayo, menjadikan lakilaki, dalam hal ini ayah, mempunyai peran yang sangat dominan dalam keluarga, baik dalam hal mendapatkan pelayanan, pengambilan keputusan, dan hal lain dalam keluarga. Suara perempuan menjadi nyaris tidak bermakna. Perempuan menjadi the second person, sehingga sistem patrilineal dalam keluarga dianggap sebagai penyebab timbulnya suborinasi perempuan.

Seperti dinyatakan oleh Piosiadlo dan kawankawan, dalam kehidupan rumah tangga, suami sengaja menggunakan sistem partialinel, mereka tidak peka dan

51 Subordinasi menunjukkan kepada posisi inferior perempuan, kurangnya akses terhadap sumber daya dan pengambilan keputusan. Hal ini terjadi karena adanya kekuasaan laki-laki terhadap perempuan, sehingga perempuan menjadi tidak berdaya. Lihat: Abeda Sultana. "Patriarchy and Women's Subordination: A Theoretical Analysis.”The Arts Faculty Journal, (July 2010-June 2011), h. 8.

52 Hazel Reeves and Sally Baden. "Gender and Development: Concepts and Definitions. Report No.55. Prepared for the Department for International Development (DFID) for its gender mainstreaming intranet resource.(February 2000), h. 7 . 
egois, sehingga istri menjadi sangat tunduk dan takut, mereka mengganggap perempuan sebagai alat reproduktif yang menghasilkan anak, melakukan pekerjaan rumah tangga, melakukan perawatan anak dan melayani suami. ${ }^{53}$ Hal ini yang menjadikan istri the second person dalam keluarga.

Sultana menyatakan, sistem patriarki (patrilineal) merupakan hambatan utama bagi kemajuan dan perkembangan perempuan, karena sistem ini menjadikan laki-laki superior, sehingga sistem patriarki menjadi penyebab suborinasi pada perempuan. Masyarakat patriarkal memberikan prioritas mutlak kepada lakilaki dan membatasi hak asasi perempuan dan patriarki mengacu pada dominasi laki-laki baik di ranah publik maupun domestik. ${ }^{54}$

Adanya subordinasi perempuan dalam keluarga Gayo, terlihat pada saat keluarga memberikan pelayanan yang sangat istimewa hanya pada ayah, ayah memiliki barang yang tidak bisa digunakan oleh anggota keluarga lainnya, ayah juga selalu mendapatkan posisi yang superior dalam keluarga. Suara dan keputusan ayah wajib didengar dan didengar oleh seluruh keluarga dan kewajiban ibu (perempuan) mengikuti keputusan yang telah diputuskan oleh ayah.

Keadaan ini menunjukkan, system patrilineal telah menempatkan posisi ayah menjadi sangat dominan dan superior dalam keluarga. Hak ibu hilang dan ibu menjadi anggota keluarga yang inferior. Selain bertentangan dengan konsep subordinasi perempuan perspektif gender, keadaan ini juga bertentangan dengan konsep agama Islam.

Islam selalu menempatkan semua hal pada posisi

53 Laura Christina Macedo Piosiadlo. "Subordination of gender: reflecting on the vulnerability to domestic violence against women. "Esc. Anna Nery vol.18 no.4 Rio de Janeiro Esc. Anna Nery 18, 4 (Oktober/ December, 2014), h. 3.

54 Abeda Sultana. "Patriarchy and Women's Subordination: A Theoretical Analysis."The Arts Faculty Journal (July 2010-June 2011), h. 1. 
yang seimbang. Islam juga menempatkan Laki-laki dan perempuan sebagai manusia yang memiliki posisi seimbang dan sama. Meskipun demikian, masih banyak anggapan membedakan peran dan kedudukan laki-laki dan perempuan. Faktor penyebab pembedaan kedudukan ini diantaranya adanya kesalahan pemahaman dalam mengkonstruksi peran sosial antara laki-laki dan perempuan sebagai akibat dari interpretasi teks suci alQur'an secara particular dan terkesan tidak utuh. Keadaan inilah yang menyebabkan sampai saat ini system patriarki masih ada.

Berkaitan dengan nilai keadilan dan kesetaraan, Islam tidak pernah mentolerir adanya perbedaan atau perlakuan diskriminasi di antara umat manusia. ${ }^{55}$ Islam memandang antara laki-laki dan perempuan sama sebagai hamba Allah. ${ }^{56}$

Habiba dan kawan-kawan menyatakan, konsep patriarki sampai saat masih ada, di Pakistan, konsep patriarki saat ini dikenal dengan nama neopatriaki (sistem patriarki baru), konsep ini menjadikan perempuan muda (menantu) dalam keluarga didominasi oleh laki-laki dan keluarganya. ${ }^{57}$

Parveen juga menyatakan, bahwa perempuan di wilayah pedesaan di Banglaesh hidup di bawah bayangbayang suami, ayah dan anak laki-laki mereka, hal ini disebabkan sebagian besar dari mereka tidak memahami tentang kesetaraan gender dan mereka menjalani hidup berdasarkan keyakinan tradisional mereka. ${ }^{58}$

Hal ini juga terjadi pada keluarga Gayo, mereka

55 Hj. Mursyidah Thahir (ed.), Pemikiran Islam tentang Pemberdayaan Perempuan(Jakarta:PP Muslimat NU Kerjasama dengan Logos Wacana Ilmu, 2000), h. 21.

56 Pernyataan ini sesuai dengan QS. Azd-Dzariyat [51]: 56 or 0

Artinya : Dan aku tidak menciptakan jin dan manusia melainkan supaya mereka mengabdi kepada-Ku

57 Ume Habiba dan kawan-kawan. "From Patriarchy to Neopatriarchy: Experiences of Women from Pakistan." International Journal of Humanities and Social Science 6, 3 (March 2016), h. 220.

58 Shahnaj Parveen. "Gender Awareness of Rural Women in Bangladesh." Journal of International Women's Studies 9,1 (artikel 14). (September 2017), h. 265. 
meyakini laki-laki adalah imam, namun cara memahami laki-laki sebagai imam itulah yang berbeda dengan konsep Islam dan gender. Mereka meyakini, sebagai imam lakilaki tidak boleh mengerjakan pekerjaan perempuan, harus selalu dinomor satukan dan menganggap pekerjaan lakilaki pada ranah publik merupakan pekerjaan terhormat sedangkan pekerjaan perempuan pada ranah domestik merupakan pekerjaan hina. ${ }^{59}$

\section{KESIMPULAN}

Penelitian ini menunjukkan bahwa pola asuh orang tua terhadap anaknya merupakan prilaku menurun yang diturunkan dari satu generasi ke generasi berikutnya. Dengan demikian, pola asuh merupkan warisan budaya turun temurun.

Pola asuh yang terjadi pada keluarga Gayo yang berdomisili di wilayah Jakarta, Bogor, Depok, Tangerang dan Bekasi masih penuh dengan budaya Gayo dan bentuk pola asuh yang diterapkannya adalah pola asuh otoriter, dimana orang tua menuntut perilaku anak sesuai dengan yang telah diajarkannya. Bentuk pola asuh yang terjadi pada keluarga Gayo merupakan konstruk budaya

Terdapat bias gender dalam pola asuh keluarga Gayo yang berdomisili di wilayah Jakarta, Bogor, Depok, Tangerang dan Bekasi. Hal ini terlihat dari adanya perlakuan istimewa pada lakilaki, berdasarkan jenis kelamin dan bukan berdasarkan kemampuan yang dimiliki.

Bentuk bias gender yang terjadi pada keluarga Gayo adalah : stereotype (pelabelan), yaitu adanya pembagian ranah domestik dan publik, double burden (peran Ganda), yaitu perempuan yang bekerja baik pada ranah publik dan ranah domestik dan Subordinat (penomorduaan terhadap perempuan), yaitu adanya anggapan laki-laki lebih unggul dari perempuan sehingga posisi perempuan dinomor duakan.[]

59 Wawancara dengan IU di Tangerang Selatan, pada September 2017. 


\section{DAFTAR PUSTAKA}

Aziz, Asamaeny. Kesetaraan Gender dalam Perspektif Sosial Budaya. (Makasar: Yapma, 2006).

Hooks, Bell. Feminism is for Everybody: Passionate Politics (Cambrigde: South End Press, 2000).

Hurgrnje. Masyarakat Gayo dan Kebudayaan Awl Abad ke 20diterjemahkan oleh HA. Asnah (Jakarta : Balai Pustaka, 1996).

Allen, Sr Prudence Allen, RSM. "Plato, Arostoteles, And The Concept Of Woman Man in Early Jewish Philosophy." Florelegium 9 (1987) : $89-111$.

Bahasyi.Ariks Samuel "Tabula Rasa Theory: A Basis for Creativity and Inventions in Education." Journal of Resourcefulness and Distinction 11,1 (December, 2015): 1-7.

Birukou, Aliaksandr dan kawan-kawan. "A Formal definition Of Culture." Technical Report DISI-09-021Accepted for the Workshop on Modeling Intercultural Collaboration and Negotiation (MICON) at International Joint Conference on Artificial Intelligence (IJCAI'09) (June, 2009):1-17

Bornstein, Marc H." Cultural Approaches to Parenting." Psychology Press 12 (2001): 212-221

Chang, Mimi. "Cultural Differences in Parenting Styles and their Effects on Teens' Self-Esteem, Perceived Parental Relationship Satisfaction, and Self Satisfaction." Theses (Carnegie Mellon University, 2007) :1-46.

D, Baumrind, (1966). "Effects of Authoritative Parental Control on Child Behavior." Child Development, 37, 4 (1996) : 887-907.

Eagly, Alice H. and Wood,Wendy. "The Nature-Nurture Debates: 25 Years of Challenges in Understanding the Psychology of Gender."Association For Psychological Science XX(X), 1-8 (2013): 1-18.

Eagly, Alice H. and Steffen, Valerie J.. "Gender Stereotypes Stem 
From the Distribution of Women and Men Into Social Roles." Journal or Personality and Social Psychology 46, 4 (1984): 735-754.

Enrique, Jade A. Heather R. Howk, and William G. Huitt ." An Overview of Family Development." Educational Psychology Interactive. Valdosta, GA: Valdosta State University. Retrieved [date], from http://www.edpsycinteractive.org/ papers/family.pdf : 1-18.

Goswami, Sribas. "Persistent Inequalities : Sribas Goswami, American International Journal of Research in Humanities, Arts and Social Sciences, 4, 1 (September-November, 2013) : 95-101.

Joseph, Mary Venus. "Imfact of Parenting Styles onChild Development." Global Academic Society Journal 1,5 (2008) :16-25.

Mahadevappa.. "Gender Bias and Social Justice." IOSR Journal Of Humanities And Social Science (JHSS) 4, 2 (Nov. - Dec. 2012) : 42-44

Mutawakkil, M. Hajir. "Keadilan Islam dalam Persoalan Gender."Kalimah 12,2 (Maret 2014) : 69 - 89

Piosiadlo, Laura Christina Macedo . "Subordination of gender: reflecting on the vulnerability to domestic violence against women. "Rio de Janeiro Esc. Anna Nery \& , ı (Oktober/ December, 2014) : 1-6.

Rakhmawati, Istina . "Peran Keluarga dalam Pengasuhan Anak." Konseling Religi, Jurnal Bimbinan Konseling Islam 6,1 (Juni, 2015) : 1-10.

Rathje, Stefanie. “The Definition of Culture: An application-oriented overhaul." Interculture Journal (2009) : 35-51.

Ramdhani, Puput. "Pengaruh Pola Asuh Orang Tua Terhadap Prokrastinasi Akademik Pada Siswa SMP Negeri 2 Anggana." eJournal Psikologi 1, 2 (2013) : 136-147. 
Risnawati. "Peran Gana Istri Yang Bekerja dalam Membantu Ekonomi Keluarga Buruh Perkebunan Kelapa Sawit Paa PT. Bumi Mas Agro di Kecamatan Sandaran Kabupaten Kutai Timur."eJournal Sosiatri-Sosiologi, 4, 3(2016): 113126.

Reeves, Hazel and Baden, Sally. "Gender and Development : Concept and Definitions." Prepared for the Department for International Development (DFID) for its gender mainstreaming intranet resource."Bridge- Developmen Gender Report 55 (February, 2000): 1-38.

Shastri, Andrey . "Gender Inequality and Women Discrimination." IOSR Journal Of Humanities And Social Science (IOSR-JHSS) 19, 11, Ver. VII (Nov. 2014): 27-30.

Swaroopa, B. " Impact of Parenting Styles on Career Choices of Adolescents.” Journal of Education \& Social Policy 1,1 (June, 2014) : $19-22$.

Sultana, Abeda. "Patriarchy and Women's Subordination: A Theoretical Analysis." The Arts Faculty Journal, (July 2010-June 2011) : 1-18.

Turner, Erlanger A. an kawan-kawan. "The Influence of Parenting Styles, Achievement Motivation, and Self-Efficacy on Academic Performance in College Students."Journal of College Student Development,50,3, (May/June 2009) : 337346 (Article).

Zaky, Eman Ahmed. "Nature, Nurture, and Human Behavior; an Endless Debate" J Child Adolesc Behav, an open access journal 3,6 (2015) : 1-5. 